\title{
Improvement of Employee Work Performance Through Working Environment Stability at Companies in Indonesia
}

\author{
Elyda Ratna Ayu Pratama Putri ${ }^{1}$, Detak Prapanca ${ }^{2}$, Dewi Andriani ${ }^{3}$ \\ Ratnaelyda@gmail.com \\ Universitas Muhammadiyah Sidoarjo, Sidoarjo, Indonesia ${ }^{1,2,3}$
}

\begin{abstract}
This study aims to determine the effect of work placement, work discipline and work environment simultaneously and partially on work performance at PT.Sengdam Jaya Abadi Ngoro as well as knowing the variables that most influence work performance. This research was conducted with quantitative methods. The sampling technique uses purposive sampling with a sample of 81 employees. Data collection techniques used questionnaires by distributing them to respondents. Data analysis techniques in the study using multiple linear regression analysis. Hypothesis testing using simultaneous ( $\mathrm{F}$ test) partial test ( $\mathrm{t}$ test) using SPSS version 18.0 program. The results of the research based on the Validity Test show that all research instruments are valid because they have $r$ count $>r$ table. For Test Reliability of all variables obtained Cronbach's alpha value that is appropriate so that it is declared reliable. Based on the results of the hypothesis shows that work placements, work discipline and work environment simultaneously have a significant influence on employee performance at PT.Sengdam Jaya Abadi. Hypothesis testing results indicate that work placement, work discipline and work environment partially have a significant influence on employee performance at PT. Sengdam Jaya Abadi. Meanwhile, the variables that have the most significant effect on employee performance at PT.Sengdam Jaya Abadi is a work environment variable.
\end{abstract}

Keywords: work placements, work discipline, work environment, work achievement.

\section{Pendahuluan}

Sumber daya manusia adalah salah satu asset perusahaan dan salah satu faktor penting untuk mewujudkan tujuan perusahaan. Seperti aset-aset perusahaan lainnya, sumber daya manusia pun memiliki peran yang dominan dalam perusahaan yang bisa mewujudkan tujuan perusahaan, maka sudah selayaknya sumber daya manusia dijaga atau dimanajemen seperti asetaset perusahaan lainnya. Keberhasilan suatu kegiatan dalam organisasi tidak hanya ditentukan oleh suatu susunan organisasi yang lengkap, akan tetapi yang lebih penting adalah karyawan yang menduduki susunan organisasi tersebut sebagai mitra kerja antara karyawan sesuai posisinya masing-masing. .Kemajuan perusahaan dapat dilihat dari prestasi yang diberikan oleh karyawan, karena prestasi merupakan hasil dari apa yang diperoleh karyawan apakah sesuai atau tidaknya dengan harapan perusahaan. PT. Sengdam Jaya Abadi bergerak dalam bidang produksi sepatu. Yang terletak di Ds. Manduro Manggung Gajah, Kecamatan Ngoro kabupaten Mojokerto. PT. Sengdam Jaya Abadi memasarkan hasil produksinya tidak hanya di dalam negeri melainkan di ekspor ke korea juga. 
Manajemen sumber daya manusia (MSDM) merupakan bidang strategis dari organisasi. Manajemen sumber daya manusia harus dipandang sebagai perluasan dari pandangan tradisional untuk mengelola orang secara efektif dan untuk itu membutuhkan pengetahuan tentang perilaku manusia dan kemampuan mengelolanya [1].

Penempatan tenaga kerja adalah proses pemberian tugas dan pekerjaan kepada tenaga kerja yang lulus seleksi untuk dilakukan sesuai ruang lingkup yang telah ditetapkan, serta mampu mempertanggungjawabkan segala risiko dan kemungkinan-kemungkinan yang terjadi atas tugas dan pekerjaan, wewenang serta tanggung jawabnya [2].

\section{Metode}

Penelitian ini merupakan penelitian kuantitatif yang disajikan dengan angka-angka [6] dengan tujuan untuk mengetahui pengaruh variabel independen yang terdiri dari penempatan kerja, disiplin kerja, dan lingkungan kerja terhadap variabel dependen yaitu prestasi kerja. Penelitian ini dilaksanakan di salah satu perusahaan yang bergerak pada bidang jasa pembuatan sepatu yakni PT. Sengdam Jaya Abadi yang berada di Jl. Manggung Gajah Desa Manduro, Kecamatan Ngoro kabupaten Mojokerto 61385, Jawa Timur. Populasi adalah wilayah generalisasi yang terdiri atas obyek atau subyek yang mempunyai kualitas dan karakteristik tertentu yang ditetapkan oleh peneliti untuk dipelajari dan kemudian ditarik kesimpulannya [7] Pada penelitian ini jumalh sampel yang ditetapkan sebesar 81 karyawan dengan menggunakan teknik purposive sampling.

Pada penelitian ini diperlukan data-data yang bersifat kuantitatif dan kualitatif. Sumber data dalam penelitian ini berasal dari data primer dan data sekunder. Teknik analisis data dalam penelitian ini menggunakan analisis regresi linier berganda. Pengujian hipotesis menggunakan uji simultan (uji F) dan uji parsial (uji t) dengan mengunakan program SPSS versi 18.0.

\section{Pembahasan}

Berdasarkan pengujian yang telah dilakukan oleh peneliti maka diperoleh hasil seluruh item instrumen penelitian yang digunakan pada penelitian ini dinyatakan valid karena semua item dari setiap pernyataan mempunyai nilai yang signifikan $(<0,05)$, sehingga keseluruhan item dinyatakan valid.

Hasil uji reabilitas menunjukkan bahwa seluruh variabel telah memenuhi syarat reliabilitas dikarenak semua variabel memiliki nilai koefisien reabilitas cronbach alpha lebih dari 0,60. Maka dapat disimpulkan bahwa instrumen atau kuisioner yang digunakan reliabel.

Tabel 1 Hasil Analisis Linier Berganda

\begin{tabular}{|c|c|c|c|c|}
\hline \multicolumn{5}{|c|}{ Coefficients $^{\mathrm{a}}$} \\
\hline Model & $\begin{array}{l}\text { Unstandardized } \\
\text { Coefficients }\end{array}$ & $\begin{array}{l}\text { Standar } \\
\text { dized } \\
\text { Coeffici }\end{array}$ & $\mathrm{T}$ & Sig. \\
\hline
\end{tabular}




\begin{tabular}{|c|c|c|c|c|c|c|}
\hline & & B & $\begin{array}{l}\text { Std. } \\
\text { Error }\end{array}$ & Beta & & \\
\hline \multirow[t]{4}{*}{1} & $\begin{array}{l}\text { (Cons } \\
\text { tant) }\end{array}$ & 2,089 & 1,765 & & 1,183 & 240, \\
\hline & $\begin{array}{l}\text { Total } \\
\mathrm{X} 1\end{array}$ & ,200 & ,082 & ,136 & 2,428 & ,018 \\
\hline & Total X2 & 336 & ,083 & ,308 & 4,047 & ,000 \\
\hline & $\begin{array}{l}\text { Total } \\
\text { X3 }\end{array}$ & ,575 & ,076 & ,565, & 7,555 & ,000 \\
\hline
\end{tabular}

Adapun persamaan regresi linier yang didapatkan sebagai berikut:

$Y=a+\beta_{1} X_{1}+\beta_{2} X_{2}+\beta_{3} X_{3}+e Y=2,089+0,200 X_{1}+0,336 X_{2}+0,575 X_{3} e$

Berdasarkan persamaan diatas maka dapat diuraikan :

1. Penempatan Kerja (X1)

Koefisien regresi dari variabel Penempatan Kerja (X1) bernilai positif sebesar 0,200. Hal ini menunjukkan bahwa antara Penempatan Kerja (X1) dan Prestasi Kerja (Y) memiliki hubungan positif. Jika Penempatan Kerja (X1) mengalami kenaikan satu satuan, maka Prestasi Kerja (Y) akan mengalami peningkatan sebesar 0,200 atau $20,0 \%$.

2. Disiplin Kerja (X2)

Koefisien regresi dari variabel Disiplin Kerja (X2) bernilai positif sebesar 0,336. Hal ini menunjukkan bahwa antara Disiplin Kerja (X2) dan Prestasi Kerja (Y) memiliki hubungan positif. Jika Disiplin Kerja (X2) mengalami kenaikan satu satuan, maka Prestasi Kerja (Y) akan mengalami peningkatan sebesar 0,336 atau 33,6\%.

3. Lingkungan Kerja

Koefisien regresi dari variabel bernilai positif sebesar 0,575. Hal ini menunjukkan bahwa antara Lingkungan Kerja (X3) dan Prestasi Kerja (Y) memiliki hubungan positif. Jika Lingkungan Kerja (X3) mengalami satu satuan, maka Prestasi Kerja (Y) akan mengalami peningkatan sebesar 0,575 atau $57,5 \%$.

Hasil Uji Simultan

Uji $\mathrm{F}$ bertujuan untuk menguji pengaruh variabel penempatan kerja, disiplin kerja, dan lingkungan kerja secara simultan terhadap prestasi kerja karyawan.

Berdasarkan hasil pengujian hipotesis menunjukkan bahwa diperoleh nilai $\mathrm{F}$ hitung sebesar 153,661. Sehingga nilai $F$ hitung ini lebih besar daripada nilai $F$ tabel yakni sebesar 2,720. Sedangkan nilai signifikasi yang diperoleh sebesar 0,000 , jadi nilai signifikasi ini lebih kecil daripada nilai $\square$ yakni 0,05 . Karena $\left(\mathrm{F}_{\text {hitung }}>\right.$

$\mathrm{F}_{\text {tabel }}=(153,661>2,720)$ dan $(\operatorname{sig}<\alpha=0,000<0,05)$ maka Ho ditolak dan $\mathrm{H}_{1}$ diterima, artinya yakni variabel independen Penempatan Kerja $\left(\mathrm{X}_{1}\right)$, Disiplin Kerja $\left(\mathrm{X}_{2}\right)$ dan Lingkungan Kerja $\left(\mathrm{X}_{3}\right)$ secara simultan berpengaruh terhadap variabel dependen yakni Prestasi Kerja (Y) pada PT.Sengdam Jaya Abadi Ngoro. 


\section{Hasil Uji Parsial}

Pada penelitian ini, uji t bertujuan untuk menguji pengaruh variabel penempatan kerja, disiplin kerja, dan lingkungan kerja secara parsial terhadap prestasi kerja karyawan.

Berdasarkan hsil pengujian hipotesis yang dilakukan, diketahui bahwa seluruh variabel bebas yang terdiri dari variabel penempatan kerja, disiplin kerja, dan lingkungan kerja secara parsial berpengaruh signifikan terhadap prestasi kerja karyawan di PT. Sengdam Jaya Abadi Ngoro. Sedangkan, variabel yang paling berpengaruh signifikan terhadap prestasi kerja karyawan yaitu variabel lingkungan kerja. Rincian hasil analisis pengaruh variabel-variabel bebas secara parsial terhadap prestasi kerja karyawan diuraikan sebagai berikut :

a. Pengaruh Penempatan Kerja terhadap Prestasi Kerja berdasarkan hasil pengujian hipotesis yang diperoleh menyatakan bahwa variabel penempatan kerja berpengaruh signifikan terhadap prestasi kerja karyawan. Dari hasil pengolahan data diperoleh informasi bahwa Penempatan Kerja berpengaruh positif secara signifikan terhadap Prestasi Kerja dengan demikian dapat dinyatakan bahwa semakin baik sebuah Penempatan Kerja maka Prestasi Kerja juga akan semakin baik. Penempatan Kerja berkontribusi positif terhadap Prestasi Kerja sehingga bisa dikatakan bahwa semakin besar kontribusi Penempatan Kerja bisa memberikan dampak yang positif bagi Prestasi Kerja.

Hasil penelitian ini sejalan dengan penelitian yang dilakukan oleh [8] dengan hasil bahwa variabel Penempatan Kerja berpengaruh positif dan signifikan terhadap Prestasi Kerja.

Penempatan Kerja berpengaruh terhadap Prestasi Kerja di PT.Sengdam Jaya Abadi karena Penempatan Kerja yang dilakukan dalam perusahaan sudah dikatakan cukup baik, karena perusahaan menempatkan karyawan pada bidang sesuai dengan keahliannya. Apabila karyawan ditempatkan pada bidang keahliannya maka hal tersebut mampu menjadi acuan untuk semakin meningkatkan prestasi kerja. Dengan penempatan kerja yang tepat itu berarti perusahaan turut membantu karyawan dalam mencapai tujuan perusahaan sehingga perusahaan dapat mencapai tujuannya dengan cepat.

b. Pengaruh Disiplin Kerja terhadap Prestasi Kerja berdasarkan hasil pengujian hipotesis yang diperoleh menyatakn bahwa variabel disiplin kerja berpengaruh signifikan terhadap prestasi kerja karyawan. Dalam penelitian ini Disiplin Kerja dimaknai sebagai suatu bentuk tanggung jawab terhadap tugas-tugas yang diberikan untuk mendorong gairah kerja karyawan sehingga dapat mencapai tujuan perusahaan.

Dengan ini dapat dinyatakan bahwa semakin baik disiplin kerja yang diterapkan maka semakin baik pula prestasi kerja. Disiplin kerja memberikan kontribusi yang positif terhadap prestasi kerja sehingga semakin besar kontribusi disiplin kerja yang diberikan maka akan berdampak positif bagi Prestasi Kerja.

Hasil penelitian ini sejalan dengan penelitian yang dilakukan oleh [9] hasil bahwa variabel Disiplin Kerja berpengaruh secara positif dan signifikan terhadap Prestasi Kerja Karyawan.

Disiplin kerja berpengaruh terhadap Prestasi Kerja di PT.Sengdam Jaya Abadi karena Disiplin Kerja membuat karyawan mematuhi segala tata aturan yang ada diperusahaan sehingga karyawan mampu bekerja dengan nyaman. Sehingga hal ini mampu meningkatkan prestasi kerja karyawan untuk mencapai tujuan perusahaan. Dengan adanya disiplin kerja akan membuat karyawan nyaman dalam bekerja, sehingga karyawan betah untuk bekerja untuk jangka waktu yang lama. 
c. Pengaruh Lingkungan Kerja terhadap Prestasi Kerja berdasarkan hasil pengujian hipotesis yang diperoleh menyatakn bahwa variabel lingkungan kerja berpengaruh signifikan terhadap prestasi kerja karyawan. Dari hasil pengolahan data diperoleh informasi bahwa Lingkungan Kerja berpengaruh positif secara signifikan terhadap Prestasi Kerja dengan demikian dapat dinyatakan bahwa semakin baik Lingkungan Kerja maka Prestasi Kerja juga akan semakin baik. Lingkungan Kerja berkontribusi positif terhadap Prestasi Kerja sehingga bisa dikatakan bahwa semakin besar kontribusi Lingkungan Kerja bisa memberikan dampak positif bagi Prestasi Kerja.

Hasil penelitian ini sejalan dengan penelitian yang dilakukan oleh [10] dengan hasil bahwa variabel Lingkungan Kerja berpengaruh positif dan signifikan terhadap Prestasi Kerja Karyawan.

Lingkungan kerja berpengaruh terhadap Prestasi Kerja di PT.Sengdam Jaya abadi karena Lingkungan Kerja yang diterapkan dalam perusahaan tersebut membuat suasana yang nyaman dan tentram sehingga membuat para karyawan betah dengan pekerjaan yang dilakukan. Menjaga lingkungan kerja untuk tetap kondusif sangat penting karena lingkungan kerja menjadi hal utama bagi karyawan untuk melaksanakan tugas yang diberikan, karena semakin nyaman lingkungan kerja yang tercipta maka semakin mudah untuk tercapainya prestasi kerja dan tujuan perusahaan.

d. Variabel yang paling berpengaruh signifikan terhadap prestasi kerja karyawan

$\backslash$ Berdasarkan hasil pengujian hipotesis yang diperoleh menyatakan bahwa variabel lingkungan kerja adalah variabel yang paling berpengaruh signifikan terhadap prestasi kerja karyawan. Hal tersebut membuktikan bahwa Para karyawan PT.Sengdam Jaya Abadi merasa bahwa Lingkungan Kerja diperusahaan sudah sangat memadai untuk menunjang aktivitas kerja para karyawan. Dengan terpenuhi kebutuhan yang diperlukan oleh karyawan misalnya, lingkungan kerja yang nyaman, bersih, harmonisnya hubungan antar karyawan dan hubungan antara karyawan dan atasan serta bentuk-bentuk penunjang lainnya. Ketika karyawan merasa nyaman di lingkungan kerjanya, maka karyawan akan semangat dalam bekerja sehingga dapat mencapai prestasi kerja yang maksimal.

\section{Kesimpulan}

Variabel penempatan kerja, disiplin kerja, dan lingkungan kerja secara simultan berpengaruh secara signifikan terhadap prestasi kerja karyawan di PT. Sengdam Jaya Abadi Ngoro. Variabel penempatan kerja, disiplin kerja, dan lingkungan kerja secara parsial berpengaruh secara signifikan terhadap prestasi kerja karyawan di PT. Sengdam Jaya Abadi Ngoro.

Diantara variabel penempatan kerja, disiplin kerja, dan lingkungan kerja yang paling berpengaruh signifikan terhadap prestasi kerja karyawan di PT. Sengdam Jaya Abadi Ngoro adalah variabel lingkungan kerja.

\section{References}

[1] Sutrisno, Edy. 2009. Manajemen Sumber Daya Manusia. Jakarta: Prenadamedia Group.

[2] Sastrohadiwiryo, Siswanto. 2005. Manajemen Tenaga Kerja Indonesia.

[3] Siagian, Sondang. 2000. Manajemen Sumber Daya Manusia. Jakarta: PT. Bumi Aksara

[4] Sedarmayanti. 2009. Tata Kerja dan Produktivitas Kerja.Bandung: Mandar Maju.

[5] Nitisemito, Alex. S. 2008. Manajemen Personalia: Manajemen sumber Daya Manusia, Edisi 
Keempat, Ghalia Indonesia, Jakarta.

[6] Sugiyono.2013. Metode Penelitian Manajemen. Bandung: Alfabeta.

[7] Sugiyono. 2016. Metode Penelitian Kuantitatif Kualitatif dan R \& D. Bandung: Alfabeta.

[8] Lestari, Ayu Dewi. 2017. Pengaruh Penempatan Kerja, Kompensasi, dan Disiplin Kerja Terhadap Prestasi Kerja Karyawan PT.Temprina Grafika Media (Jawa Pos Group) Nganjuk. Artikel SimkiEconomic Vol. 01 No. 04, 2017.

[9] Irawati Dwi, Mustakim Noor. 2012. Pengaruh Komitmen Organisasional, Disiplin Kerja dan Motivasi Kerja Terhadap Prestasi Kerja Pegawai Balai Pelaksana Teknis Bina Marga Wilayah Magelang. Majalah Ekonomi. No. 1.2012.

[10] Rianti, Rasi. 2018. Pengaruh Lingkungan Kerja dan Displin Kerja Terhadap Prestasi Kerja Karyawan Pada PT. Karet Andalas Agrolestari Kabupaten Kuantan Singingi. JOM FISIP Vol. 5: Edisi I Januari - Juni 2018. 